\title{
UPAH MINIMUM TENAGA KERJA KOTA BATAM DITINJAU DARI UNDANG-UNDANG KETENAGAKERJAAN
}

\author{
Pristika Handayani \\ Dosen Tetap Program Studi Ilmu Hukum Universitas Riau Kepulauan
}

\begin{abstract}
Abstrak
Upah adalah salah satu kewajiban pengusaha yang harus diberikan kepada pekerja/buruh. Setelah menyelesaikan tugas dan kewajiban maka pekerja berhak untuk mendapatkan upah. Batam merupakan salah satu kota propinsi yang standarisasi tingkat kehidupan yang tinggi, oleh karena itu upah minimum pekerja juga lebih tinggi dibanding dengan propinsi yang lain. Adanya kenaikan upah minimum kota (UMK) sebagai sarana bagi pihak manajemen dan serikat pekerja untuk merundingkan secara bipartite kenaikan upah sundulan atas kenaikan upah minimum.
\end{abstract}

Kata kunci: upah, pengusaha, pekerja

\begin{abstract}
Wages are one of the employer's obligation is to be given to workers / laborers. After completing the tasks and obligation, the worker is entitled to get wages. Batam is one of the provincial towns that standardized high level of life, therefore the minimum wage is also higher than other provinces. Wages can be increase in town or province (UMK) as a place to management people and trades union to discuss about wages of worker with bipartite system.
\end{abstract}

Keywords: wages, employer, worker

\section{A. Pendahuluan}

Pasal 1 angka 2 Undang-Undang No.13 Tahun 2003 Tenaga kerja adalah setiap orang yang mampu melakukan pekerjaan guna menghasilkan barang atau jasa untuk memenuhi kebutuhan sendiri maupun masyarakat.

Upah adalah segala macam pembayaran yang timbul dari kontrak kerja, terlepas dari jenis pekerjaan dan denominasinya. Upah menunjukkan penghasilan yang diterima oleh pekerja sebagai imbalan atas pekerjaan yang dilakukannya. Upah dapat diberikan dalam bentuk tunai atau natura. Sistem pengupahan di Indonesia pada umumnya didasarkan pada tingkat fungsi upah, yaitu menjamin kehidupan yang layak bagi pekerja dan keluarganya, mencerminkan imbalan atas hasil kerja seseorang, dan keluarganya, mencerminkan imbalan atas hasil kerja seseorang, dan menyediakan insentif untuk mendorong peningkatan produktivitas kerja.

Pekerja yang bekerja mengharapkan upah atau honor sebagai imbalan dari jerih payah yang sudah dilakukan. Disetiap kota atau propinsi mempunyai standarisasi pengupahan terhadap para pekerjanya. Perbedaan setiap propinsi dibedakan pengupahan disesesuaikan karena kebutuhan sembako atau bahan pokok disuatu propinsi tersebut.

Upah Minimum adalah suatu standar minimum yang digunakan oleh para pengusaha atau pelaku industri untuk memberikan upah kepada pekerja dilingkungan usaha atau kerjnya. Karena pemenuhan kebutuhan yang layak disetiap provinsi berbeda-beda, maka disebut upah minimum provinsi.

Upah minimum provinsi bisa dilihat pada setiap provinsi berbeda-beda dimana didalam pembahasan dan penetapannya tidak hanya memperhatikan kondisi didaerah tersebut tetapi suatu wilayah yang berada diluar jakartapun bias memiliki upah minimum provinsi yang lebih tinggi apalagi jika wilayah di provinsi tersebut banyak akan bahan baku dan merupakan wilayah industri yang tentunya dengan semakin berkembangnya industry tersebut akan berakibat juga dengan makin tingginya harga kebutuhan bahan pokok dan ini bias berakibat pemerintah menetapkan Upah minimum provinsi yang lebih lagi untuk pekerja/buruh didaerah itu.

Perbedaan tingkat upah terletak dari satu sektor ke sektor industri lainnya ataupun antar daerah. Perbedaan ini pada dasarnya disebabkan oleh satu atau lebih dari alasan berikut:

1. Pada dasarnya pasar kerja terdiri atas beberapa pasar kerja yang berbeda dan terpisah satu sama lain. Pada satu pihak, pekerjaan yang berbeda memerlukan tingkat pendidikan dan keterampilan yang berbeda. Produktivitas kerja seseorang berbeda menurut pendidikan dan latihan yang diperolehnya. Perbedaan tingkat upah dapat terjadi karena perbedaan tingkat pendidikan, latihan, dan pengalaman.

2. Tingkat upah ditiap perusahaan berbeda menurut persentase biaya pekerja terhadap seluruh biaya keseluruhan, semakin tinggi tingkat upah. Misalnya pada perusahaan-perusahaan yang padat modal, seperti perusahaan minyak, pertambangan dan industry berat.

3. Perbedaan tingkat upah anatara beberapa perusahaan dapat pula terjadi menurut perbedaan proporsi keuntungan perusahaan terhadap penjualannya. Semakin besar proporsi keuntungan terhadap penjualan dan semakin besar proporsi keuntungan terhadap penjualan dan semakin besar jumlah absolute keuntungan, semakin tinggi nilai upah. 
4. Perbedaan tingkat upah antar perusahaan dapat berbeda karena perbedaan peranan pengusaha yang bersangkutan dalam menentukan harga. Perusahaan monopoli dapat menaikkan harga tanpa takut akan kompetensi. Adapun pengusaha oligopoly lebih mudah untuk bersama-sama berunding menentukan harga sehingga tidak perlu berkompetensi satu sama lain. Dalam perusaahaan-perusahaan tersebut lebihan mudah untuk menimpakan kenaikan upah pada harga jual barang.

5. Tingkat upah dapat berbeda menurut besar kecilnya perusahaan. Perusahaan yang besar dapat memperoleh kemanfaatan "economic of scale" sehingga dapat menurunkan harga, dan mendominasi pasar. Dengan demikian, perusahaan yang besar cenderung lebih mampu memberikan tingkat upah yang tinggi daripada perusahaan kecil.

Sistem pengupahan yang berlaku pada umumnya di Indonesia dipengaruhi oleh kebijakan pemerintah dalam memberlakukan upah minimm kota (UMK) dan upah minimum propinsi (UMP) yaitu pada setiap tanggal 1 Januari pada setiap tahunnya. Dengan adanya Pemberlakuan sistem upah minimum menimbulkan dampak yang positif maupun negatif terhadap sistem pengupahan yang berlaku khusus ditingkat perusahaan.

Pada setiap kota ataupun propinsi mempunyai pemberlakukan kebijakan terhadap upah buruh. Perbedaanperbedaan yang sangat signifikan adalah dikarenakan kebutuhan pangan disetiap kota ataupun propinsi yang berbeda menyebabkan upah minimum untuk buruh harus disesuaikan.

Kota Batam adalah kota terbesar di Kepulauan Riau dan merupakan kota dengan populasi terbesar ke tiga di wilayah Sumatra setelah Medan dan Palembang, Menurut Dinas Kependudukan dan Catatan Sipil Kota Batam Per April 2012 jumlah penduduk Batam mencapai 1.153.860 jiwa. Metropolitan Batam terdiri dari tiga pulau, yaitu Batam, Rempang dan Galang yang dihubungkan oleh Jembatan Barelang. Batam merupakan sebuah kota dengan letak sangat strategis. Selain berada di jalur pelayaran internasional, kota ini memiliki jarak yang cukup dekat dengan Singapura dan Malaysia. Batam merupakan salah satu kota dengan pertumbuhan terpesat di Indonesia. Ketika dibangun pada tahun 1970-an awal kota ini hanya dihuni sekitar 6.000 penduduk dan dalam tempo 40 tahun penduduk Batam bertumbuh hingga 158 kali lipat.

Pulau batam dihuni pertama kali oleh orang melayu dengan sebutan orang selat sejak tahun 231 Masehi. Pulau yang pernah menjadi medan perjuangan Laksamana Hang Nadim dalam melawan penjajah ini digunakan oleh pemerintah pada dekade 1960-an sebagai basis logistik minyak bumi di Pulau Sambu.

Pada dekade 1970-an, dengan tujuan awal menjadikan Batam sebagai Singapura-nya Indonesia, maka sesuai Keputusan Presiden nomor 41 tahun 1973, Pulau Batam ditetapkan sebagai lingkungan kerja daerah industri dengan didukung oleh Otorita Pengembangan Daerah Industri Pulau Batam atau lebih dikenal dengan Badan Otorita Batam (BOB) sekarang dengan nama Badan Penguasaan (BP) Batam sebagai penggerak pembangunan Batam.

seiring pesatnya perkembangan Pulau Batam, pada dekade 1980-an, berdasarkan Peraturan Pemerintah Nomor 34 tahun 1983, wilayah kecamatan Batam yang merupakan bagian dari kabupaten Kepulauan Riau, ditingkatkan statusnya menjadi Kotamadya Batam yang memiliki tugas dalam menjalankan administrasi pemerintahan dan kemasyarakatan serta mendudukung pembangunan yang dilakukan Otorita Batam.

Di era reformasi pada akhir dekade tahun 1990-an, dengan Undang-Undang nomor 53 tahun 1999, maka Kotamadya administratif Batam berubah statusnya menjadi daerah otonomi, yaitu Pemerintah Kota Batam untuk menjalankan fungsi pemerintahan dan pembangunan dengan mengikutsertakan Badan Otorita Batam.

\section{B. Permasalahan}

Isu kenaikan bahan bakar minyak atau yang lebih sering kita dengar dengan istilah BBM akan beranjak naik. Selepas dilantiknya Presiden Joko Widodo, maka harga BBM pun ikut naik. Terkait dengan hal tersebut maka berpengaruh pesat terhadap upah para pekerja. Bagaimana upah pekerja yang ada di Indonesia khususnya kota batam berdasarkan Undang-Undang Ketenagakerjaan? Upah yang selama ini selalu diperdebatkan oleh para pekerja membuat gejolak dan pemerintah harus kerja keras untuk ikut dalam membahas mengenai upah bagi para pekerja yang ada di Indonesia. Setiap kota atau propinsi pasti mempunyai standarisasi terhadap UMK atau UMP.

Batam merupakan salah satu kota yang UMK pekerja nya terbilang besar dibanding dengan kota-kota lainnya. Untuk saat ini UMK yang ada di kota batam adalah Rp. 2.400.000,- (Dua Juta Empat Ratus Ribu Rupiah). Perbedaan besar kecil upah yang diterima pekerja juga disesuaikan dengan waktu kerja dan juga berdasarkan jabatan dan lain-lain.

\section{Pembahasan}

Ditetapkannya batam sebagai kawasan perdagangan bebas dan pelabuhan bebas atau lebih dikenal denangan Free Trade Zone (FTZ) dengan peraturan pemerintah (PP) Nomor 46 Tahun 2007. Menjadikan pulau batam sebagai FTZ adalah merupakan mimpi panjang yang tidak singkat dan akhirnya menjadi kenyataan. Segala perjuangan sudah dilakukan oleh semua pihak untuk mendapatkan status tersebut dari Pemerintah Pusat. Semacam kemurahan hati seorang Presiden RI yang akan mem berikan fasilitas khusus kepada Pulau Batam untuk dimanfaatkan bagi kepentingan-kepentingan kelompok usaha atau hanya kelompok tertentu. 
Masalah upah adalah masalah klasik dalam persoalan buruh di Indonesia. System pengupahan yang ada sekarang dianggap tidak adil, standar upah yang ditetapkan pemerintah berlaku sama tanpa membedakan perusahaan besar atau kecil, perusahaan yang orientasi export atau domestik, hotel bintang atau melati.

Kenaikan UMK nantinya akan dirundingkan oleh pihak perusahaan yaitu disisni adalah manajemen dan juga serikat pekerja yang dilakukan secara bipartite. Antara kedua belah pihak akan merundingkan dan juga akan membentuk Tim untuk membahas kenaikan bagi para pekerja.

Sistem penguphan merupakan kerangka pengaturan pelaksanaan pengupahanberdasarkan kepada kebutuhan yang layak bagi buruh dan keluarganya yang terdiri dari upah pokok dan tunjangan atau pendapatan lain dalam bentuk upah. Dalam pelaksanaan pengupahan diatur tata cara pembayaran dan jangka waktu pembayaran upah. Dalam sistem pengupahan di Indonesia, pemerintah berwenang menetapkan Upah Minimum Propinsi (UMP) dan upa Minimum Kota (UMK) Berdasarkan Peraturan Menteri Kerja Nomor 7 Tahun 2013 tentang Upah Minimum.

Pemerintah mempunyai kebijakan untuk melindungi pekerja atau buruh, seperti yang disebutkan dalamPasal 88 ayat 1 Undang-Undang Nomor 13 Tahun 20013 tentang Ketenagakerjaan, yaitu:

"bahwa pekerja/buruh berhak memperoleh penghasilan yang memenuhi penghidupan yang layak bagi kemanusiaan."

Pada Pasal 94 menyebutkan mengenai komponen upah yang terdiri dari upah pokok dan tunjangan tetap, maka besarnya upah pokok sedikit-dikitnya $75 \%$ (tujuh puluh lima persen) dari jumlah upah pokok dan tunjangan tetap.

Pembagian komponen upah biasanya terdiri dari:

1. Upah pokok ditambah tunjangan tetap (all in)

2. Upah pokok ditambah tunjangan tetap dan tidak tetap

3. Upah tidak terbagi kedalam komponen-komponen, gaji yang di terima pekerja adalah total keseluruhan (clean wage)

Berkaitan dengan tunjangan yang diberikan perusahaan pada pekerja/buruh dibagi menjadi:

1. Tunjanga tetap

Tunjangan tetap adalah tunjangan yang diberikan oleh perusahaan secara rutin kepada pekerja/buruh perbulan yang besarnya relatif tetap.

Contoh: tunjangan jabatan, tunjangan keluarga, tunjangan keahlian/profesi.

2. Tunjangan tidak tetap

Tunjangan tidak tetap adalah tunjangan yang diberikan oleh perusahaan kepada pekerja/buruh dimana penghitungannya berdasarkan kehadiran atau performa kerja.

Contoh: tunjangan transportasi, tunjangan makan, insentif dan biaya operasional.

Berdasarkan Keputusan Gubernur Kepulauan Riau Nomor 984 tahun 2013 tentang penetapan upah minimum Kota Batam Tahun 2014, Upah Minimum Kota (UMK) Kota Batam ditetapkan sebesar Rp. 2.422.092,- (Dua Juta Empat Ratus Dua Puluh Dua Ribu Sembilan Puluh Dua Rupiah). Dengan demikian setiap pelaku industri ataupun pengusaha harus membayar upah karyawan/Tenaga Kerjanya berdasarkan keputusan Gubernur tersebut. Di samping itu, Gubernur juga menetapkan Upah Minimum Sektor (UMS) berdasarkan persentase dari UMK (Upah Minimum Kota) yang telah ditetapkan tadi. Penetapan UMS tersebut dituangkan dalam Keputusan Gubernur Kepulauan Riau Nomor 997 Tahun 2013 tentang penetapan Upah Minimum Sektor (Kota Batam) Tahun 2014. UMS 2014 ini dibagi menjadi 3 Kelompok lapangan usaha.

Berikut ini adalah 3 Kelompok Lapangan Usaha beserta besarnya Upah Minimum Sektor (UMS) dari 3 Kelompok tersebut:

1. Upah Minimum Kota (UMK) Rp. 2.422.092,- Upah Minimum Sektor (UMS) Kelompok 1 Rp. 2.640.080,- $(9 \%$ lebih tinggi dari UMK Kota Batam)

a. Pertambangan, minyak bumi. gas alam dan panas bumi

b. Industri makanan

c. Industri bahan dan barang kimia dari bahan kimia (Kimia Dasar)

d. Industri barang galian bukan logam

e. Industri Logam dasar

f. Industri Barang Logam, kecuali mesin dan peralatannya

g. Industri Alat angkut lainnya

h. Jasa Reparasi dan pemasangan mesin dan peralatannya

i. Pengadaan Air

j. Konstruksi Gedung

k. Konstruksi Bangunan Sipil

2. Konstruksi Khusus Upah Minimum Sektor (UMS) Kelompok 2 Rp. 2.494.755,(3\% lebih tinggi dari UMK Kota Batam)

a. Industri bahan dan barang kimia dari bahan kimia (plastik, karet)

b. Industri Farmasi, obat dan jamu

c. Industri Karet, barang dari karet dan plastik

d. Industri Barang Logam, kecuali mesin dan peralatannya (Penempaan, pengepresan dan pecetakan)

e. Industri Komputer, Barang Elektronik dan Optik

f. Industri Peralatan Listrik 
I. Industri Mesin dan perlengkapannya

m. Industri Kendaraan bermotor, trailer dan semi trailer

n. Industri Pengolahan lainnya.

3. Pengadaan Listrik, Gas, Uap/air panas dan udara dingin Upah Minimum Sektor (UMS) Kelompok 3 Rp.

2.470.534,- (2\% lebih tinggi dari UMK Kota Batam)

a. Pertanian, perternakan, perburuan dan kegiatan YBDI

b. Industri Tekstil

c. Industri Pakaian Jadi

d. Industri Kulit, barang dari Kulit dan alas kaki

e. Industri Kertas dan barang dari Kertas

f. Perdagangan besar kecuali Mobil dan sepeda motor

g. Penyediaan Akomodasi

h. Penyediaan Makan dan Minuman

i. Jasa Keuangan dan Asuransi

j. Real Estate

k. Jasa Agen perjalanan, Penyelenggaraan Tur dan jasa reservasi lainnya

I. Kegiatan Olahraga dan rekreasi lainnya

Koordinator Garda Metal FSPMI Kota Batam, Suprapto yang mematok angka minimal Rp2,5 hingga Rp3 juta sebagai Upah Minimum Kota (UMK) Batam 2014. "Untuk standar Batam, Rp2 juta masih kurang. Hitung-hitungan kita, justru antara Rp2,5-3 juta," ungkapnya di Mukakuning, Batam, Senin (13/2).

Patokan UMK Batam sebesar Rp2,5 juta dinilainya sebagai angka yang wajar. Karena semakin meningkatnya kebutuhan hidup layak dari waktu ke waktu. Jika patokan UMK Batam di bawah Rp2,5 juta, akan sulit bagi buruh memenuhi standar kebutuhannya. Dengan adanya upah minimum yang sesuai dengan kebutuhan, maka diharapkan akan meningkatkan etos kerja dan produktifitas buruh. "Semakin bagus kesejahteraan buruh, maka akan semakin meningkat juga produktifitasnya.

Upah minimum dirahkan untuk pencapaian kebutuhan yang lebih layak. Upah minimum dengan memperhatikan rekomendasi dari Dewan Pengupahan Provinsi dan/atau Bupati/Walikota.

Pengusaha dilarang membayar upah lebih rendah dari upah minimum. Bagi pengusaha yang tidak mampu membayar upah minimum dapat dilakukan penangguhan.

Pengaturan pengupahan yang ditetapkan atas kesepakatan antara pengusaha dan pekerja/buruh atau serikat pekerja/serikat buruh tidak boleh lebih dari ketentuan pengupahan yang ditetapkan peraturan perundangundangan, kesepakatan tersebut batal demi hukum dan pengusaha wajib membayar upah pekerja/buruh menurut peraturan perundang-undangan yang berlaku.

Pengusaha menyusun struktur dan skala upah dengan memperhatikan golongan, jabatan, masa kerja, pendidikan dan kompetensi. Pengusaha melakukan peninjauan upah secara berkala dengan memperhatikan kemampuan perusahaan dan produktivitas.

\section{Penutup}

Untuk memberi saran, pertimbangan dan merumuskan kebijakan pengupahan yang akan ditetapkan oleh pemerintah, serta untuk pengembangan sistem pengupahan nasional dibentuk Dewan Pengupahan Nasional, Provinsi dan Kabupaten/Kota. Keanggotaan Dewan Pengupahan terdari dari undur pemerintah, organisasi pengusaha, serikat pekerja/serikat buruh, perguruan tinggi dan pakar. Keanggotaan Dewan Pengupahan Tingkat Nasional diangkat dan diberhentikan oleh Presiden, sedangkan keanggotaan Dewan pengupahan Provinsi, Kabupataen/kota diangkat dan diberhentikan oleh Gubernur/Bupati/Walikota.

Besar kecilnya upah yang didapat pekerja disesuaikan dengan provinsi dan juga disesuaikan dengan kebutuhan sembako tiap kota itu sendiri. Dengan adanya kenaikan BBM atau bahan bakar minyak maka akan mempengaruhi harga sembako dan juga berpengaruh terhadap pendapatan atau upah pekerja. Pada saat sekarang ini pemerintahan kota batam sedang berdiskusi dengan pihak-pihak terkait mengenai kenaikan upah buruh.

\section{DAFTAR PUSTAKA}

Abdussalam, Hukum Ketenagakerjaan (Hukum Perburuhan), Restu Agung, Jakarta, 2009

Hadi Setia Tunggal, Seluk Beluk Hukum Ketenagakerjaan, Harvarindo, Jakarta, 2014

Lalu Husni, Pengantar Hukum Ketenagakerjaan, Rajawali Press, Jakarta, 2014

Rekson Silaban "Reposisi gerakan buruh: Peta Jalan Gerakan Buruh Inonesia Pasca Reformasi” Jakarta, pustaka sinar harapan, 2009. 
Rachmat Trijono, Pengantar Hukum Ketenagakerjaan, Papas Sinar Sinanti, Jakarta, 2014

R. Joni Bambang, S, S.H,.M.M, Hukum Ketenagakerjaan, Pustaka Setia Bandung, Bandung, 2013

Rukiyah L \& Darda Syahrizal, Undang-Undang Ketenagakerjaan dan Aplikasinya, Dunia Cerdas, Jakarta, 2013

Ta'in Komari, Batam Tergadai 70 Tahun”Eska Media, Jakarta, 2008

Muhaimin Iskandar, http://www.harianhaluan.com/index.php/berita/riau-a-kepri/12638-umk-batam-2014-minimalrp25-juta

http://id.wikipedia.org/wiki/Kota Batam

www.ut.ac.id/html/suplemen/..../SISTEM\%20PENGUPAHAN 